Prace Literackie LVIII

Wrocław 2018

https://doi.org/10.19195/0079-4767.58.4

\author{
JOANNA ŻYTEK
}

ORCID: 0000-0002-5878-2207

Katolicki Uniwersytet Lubelski Jana Pawła II

\title{
„Myż to, Polacy, owych mężów plemię...”- miejsce liryki patriotycznej w twórczości Franciszka Dionizego Kniaźnina
}

Jednym z najistotniejszych tematów będących przedmiotem zainteresowania pisarzy polskiego oświecenia było odwzorowywanie w swoich dziełach sytuacji społecznej i politycznej, w jakiej znalazła się wówczas Rzeczpospolita ${ }^{1}$. Choć w utworach tych można dostrzec pewne spójne motywy, o których pisała między innymi Teresa Kostkiewiczowa w swojej klasycznej już rozprawie Horyzonty wyobraźni ${ }^{2}$, akcenty narodowe u poszczególnych poetów tego okresu rozkładały się różnorodnie. Jedni, zwłaszcza klasycyści, koncentrowali się na dydaktyzmie i z wszystkich sił starali się rozbudzać w narodzie otwartość na niezbędne reformy. Inni, zwłaszcza po trudnych doświadczeniach rozbiorów, popadali w poetyckie przygnębienie i marazm, ubolewając w swoich tekstach nad losem ojczyzny. Jeszcze inni starali się propagować polskość i wszystko, co z nią związane, a więc narodową kulturę, tradycję i obyczajowość, odwracając się od tak modnych wówczas wzorów z zachodnich dworów.

Naszym celem jest przejrzeć się dziś w zwierciadle poezji patriotycznej Franciszka Dionizego Kniaźnina. Co w nim zobaczymy? Spróbujemy zdefiniować, w jaki sposób ukazany jest patriotyzm w utworach poety z Witebska, i porównać, czym jego obrazowanie ojczyzny różni się od spojrzenia innych twórców tego okresu, a także jak ewoluowało ono u samego Kniaźnina. Podejmiemy też próbę

${ }^{1}$ Jan Kott w broszurce Trwałe wartości literatury polskiego oświecenia wskazywał, że troska o język narodowy, pokazywanie cnót narodowych, wychowywanie społeczeństwa, powołanie teatru narodowego, włączanie do literatury słownictwa ludowego, które „wzbogaca i unarodowania język literacki epoki”, są nieodłącznie związane z twórczością wieku XVIII. Por. idem, Trwałe wartości literatury polskiego oświecenia, Kraków 1951, s. 32.

2 T. Kostkiewiczowa, Horyzonty wyobraźni. O języku poezji czasów Oświecenia, Warszawa 1984. 
uzasadnienia, że nie tylko liryka miłosna czy religijna, lecz także ta podejmująca tematykę ojczyźnianą może być traktowana jako „pierwiosnek romantyzmu” w twórczości śpiewaka Temiry. Z konieczności będziemy musieli dokonać pewnych uogólnień, pokazując jedynie pewne tendencje w twórczości patriotycznej poety.

\section{Kniaźninowskie rozumienie patriotyzmu}

Wiek XVIII był czasem redefinicji pojęcia patriotyzmu. Powoli kształtowało się nowożytne rozumienie narodu, w którym było miejsce dla wszystkich stanów ${ }^{3}$. W kulturze oświeceniowy patriotyzm przejawiał się w dwóch postawach: $\mathrm{z}$ jednej strony coraz większą otwartością na obce, zwłaszcza francuskie wzory ${ }^{4}$, mocne w środowisku królewskim, z drugiej zaś ze swoistą modą na polskość, zauważalne w gloryfikowaniu narodowych zwyczajów, mowy i strojów, podtrzymywane zwłaszcza przez środowisko dworu w Puławach ${ }^{5}$, z którym związany był Kniaźnin.

Patrząc na działalność narodową Adama Kazimierza i Izabeli Czartoryskich, poeta napisał wiele dzieł, w których kreuje wzór Polaka - oddanego swojej ojczyźnie, wychowującego dzieci z myślą o niej i bardziej ceniącego dobro narodu niż własne. „Choroba na Polskę” księżnej Izabeli udzielała się Kniaźninowi, który pod jej wpływem w 1786 roku napisał operę Matka Spartanka. W tym heroicznym dziele, w którego przygotowanie i wystawienie włączyła się sama księżna i jej synowie, widzimy najlepsze cnoty obywatelskie, a ich wyrazicielami były wszystkie warstwy społeczne. Co znamienne, o zwycięstwie Sparty decydowało niemal w takim samym stopniu męstwo żołnierzy, jak i oddanie Sparta$n^{6}{ }^{6}$. I jeżeli szukać w dorobku śpiewaka Temiry potwierdzenia słów Stanisława Tarnowskiego z początku XX wieku, że Kniaźnin był „prekursorem [...] poezji romantycznej"7, dokonuje się to właśnie w jego widzeniu roli kobiety dla narodu, które podjął później Mickiewicz w liryku rzymsko-drezdeńskim Do Matki Polki. Cnotliwe Spartanki, potrafiące zagrzewać synów do walki w obronie ojczyzny, łączą w sobie ideały obywatelskie i religijne, gdyż sprawę narodową zawierzają Bogu. Teona otwarcie wyznaje Likanorowi:

Rada bym jeszcze natchnąć cię goręcej!

Kocham cię, synu, lecz ojczyznę więcej.

Ojczyzna i serc, i dóbr naszych pani,

${ }^{3}$ Por. A.M. Stasiak, Patriotyzm w myśli konfederatów barskich, Lublin 2005; B. Jedynak, „Aby potomkowie byli Polakami”. Z historii refleksji nad obyczajem w oświeceniu, Lublin 2001.

${ }_{4}^{4}$ Por. A. Roćko, Kontusz i frak. O symbolice stroju w XVIII-wiecznej literaturze polskiej, Warszawa 2015.

5 Por. J. Snopek, Oświecenie. Szkic do portretu epoki, Warszawa 1999, s. 86-87.

${ }^{6}$ Por. A. Jendrysik, Wstęp, [w:] F.D. Kniaźnin, Utwory dramatyczne. Wybór, oprac. A. Jendrysik, Warszawa 1958, s. 38.

${ }^{7}$ S. Tarnowski, Historia literatury polskiej, t. 3, Kraków 1904, s. 385. 
Ty u mnie jesteś i po niej, dla niej.

Skoroś jej niewart, nie jesteś mym synem ${ }^{8}$. (w. 107-111)

Hańba syna jest zgubą i wstydem matki, jego zaś wierność Ojczyźnie jej największym powodem chluby. Teona jest nie tylko matką Likanora, lecz także matką narodu, wspiera spartańskie dziewczęta, dodając im otuchy i przypominając o męstwie wojowników:

Dziewczęta płoche, czego się lękacie?

Spartańskiej cnoty jeszcze wy nie znacie.

Pótyśmy wolne, póty Sparta słynie,

Póty z jej synów ostatni nie zginie. (w. 185-188)

Choć Kniaźnin wybrał sztafaż antyczny, wszyscy współcześni doskonale rozpoznawali w dzielnej Teonie księżnę Izabelę. Potwierdzają to przedmowa autora, a także dwa dołączone do wydania Matki Spartanki wiersze: Stanisława Potockiego wojewody ruskiego do księżny Izabeli Czartoryskiej generałowej ziem podolskich oraz Juliana Ursyna Niemcewicza ${ }^{9}$ Do Polek, zachęcające polskie kobiety, aby stawały się niczym tytułowa Matka Spartanka Kniaźnina:

O wy, Polki! Jeśli wam serce dziś przenika

Widok cnotliwej matki, syna wojownika,

Jeśli was bolą Polski i hańba, i blizny,

Wpajajcie w synów męstwo i miłość Ojczyzny.

Matki na wzór Spartanek! [... $]^{10}$ (w. 3-7)

Czartoryscy widziani w zwierciadle Kniaźnina zostali celowo zmitologizowani $^{11}$ i wyidealizowani. Księżna Izabela to pierwowzór liryku-kołysanki Matka Obywatelka, której największą troską jest wychowanie patriotyczne swojego dziecka $^{12}$. Cnoty obywatelskie księcia Adama Jerzego Czartoryskiego chwalą liczne liryki jemu poświęcone, między innymi tekst Do księcia Adama Jerzego Czartoryskiego na obóz pod Gotębiem. Adresat liryczny został w nim ukazany niczym pełen werwy, zapału i radości młody rycerz, który nie żałuje swoich sił dla Ojczyzny:

Żyje Ojczyzna i Polaków chwała! [...]

Widzę z radością młodego rycerza.

Czy szablą łaska, czy na koniu toczy,

${ }^{8}$ F.D. Kniaźnin, Utwory dramatyczne..., s. 72.

9 To właśnie od Kniaźnina zaczerpnie patriotyzm Matki Spartanki Julian Ursyn Niemcewicz do swojego Powrotu posła, którego premiera odbyła się w styczniu 1791 roku. Por. D. Ratajczakowa, Obrazy narodowe w dramacie i teatrze, Wrocław 1994, s. 39.

10 J.U. Niemcewicz, Do Polek, [w:] F.D. Kniaźnin, Utwory dramatyczne..., s. 97.

${ }^{11}$ Por. J. Lenkiewiczowa, Odbiór księżnej Izabeli Czartoryskiej przez jej wspótczesnych ukazanie patriotyzmu księżnej, „Kamerton” 2006, nr 1, s. 54-63.

${ }^{12} \mathrm{Z}$ nieco inną konwencją spotykamy się u innego sentymentalisty, Franciszka Karpińskiego, w wierszu O powinnościach obywatela. Na rocznicę urodzenia tegoż księcia, który podobne przesłanie wkłada w usta samej ojczyzny. Wiersz jest także dedykowany księciu Adamowi Czartoryskiemu. 
Kurz na nim i znój porywa me oczy

I w duszę ogniem uderza ${ }^{13}$. (w. 1, 5-8)

Za owo poświęcenie sama Ojczyzna zgotuje mu wieniec chwały i przyjmie na swoje łono. Co więcej, Polska została w tym wierszu upersonifikowana jako ta, która „i dzielność, i z usługą imię, i prawo waży człowieka”"14 (w. 11-12), co może oznaczać, że dla Kniaźnina miarą wartości osoby ludzkiej staje się jej patriotyzm i ofiarność dla sprawy narodu. Obywatelem zaś, w myśl wiersza Do obywatela, mianuje poeta tego, „co swymi trudy/ wspiera los braci, choć przeciwność bije”"15 (w. 5-6), kto z miłości do kraju potrafi porzucić swoje zajęcia, by zjednoczyć się w walce o wolność, i tego, dla którego dobro wspólne jest cenniejsze niż osobiste korzyści.

\section{Mit przodków poczciwych w realizacji Kniaźnina. Tony nadziei i katastrofy}

Zgodnie z konwencją epoki Kniaźnin również przywołuje w swoich utworach mit przodków poczciwych. Powołuje się na nich, aby ukazać kontrast między ich oddaniem sprawie ojczystej, a opieszałością jemu współczesnych. Stosunek Kniaźnina do historii jest sentymentalny, a nawet romantyczny — być może ma to związek z thumaczonymi przez poetę w Puławach Pieśniami Osjana. Twórczość poety z Witebska, podobnie jak u Macphersona, wyróżniała się uczuciowym podejściem do bohaterskiej przeszłości poprzednich pokolen ${ }^{16}$. W odróżnieniu od Naruszewicza czy Krasickiego jego odwoływanie się do przodków nie jest ogólnikowe - poeta wymienia konkretne postaci historyczne, wysławiając ich zasługi $^{17}$, podobnie jak czynił to Julian Ursyn Niemcewicz w swoich dumach historycznych. Kniaźnin bardzo chętnie w zwierciadle swoich tekstów odbija postać Jana III Sobieskiego, jak na przykład w utworach Do Krakowa, Do wąsów oraz Na stoletni obchód zwycięstwa Jana III pod Wiedniem. W ostatnim z nich nazywa króla „gromcą niewiernych” i „Janem z nieba zesłanym”18 (w. 10), podkreślając jednocześnie, że opiewane zwycięstwo było zasługą jednomyślności narodu i zgody, bez której chwała pojedynczego człowieka byłaby niemożliwa. Przywołuje też Kniaźnin postać Czarnieckiego, który „słynął żelazem/ i dla ojczyzny krew swą poświęcił"19 (w. 13-14), jak czytamy w wierszu Do wąsów, w liryku zaś Do Krakowa odmalowuje sylwetki poszczególnych władców Polski, między

${ }^{13}$ F.D. Kniaźnin, Do księcia Adama Jerzego Czartoryskiego na obóz pod Gołębiem, [w:] idem, Wiersze wybrane, oprac. A.K. Guzek, Warszawa 1981, s. 153 (dalej: WW i numer strony).

14 Ibidem.

15 F.D. Kniaźnin, Do obywatela, WW, s. 132.

${ }^{16}$ Por. Z. Sinko, Osjanizm, [w:] Stownik literatury polskiego oświecenia, red. T. Kostkiewiczowa, Wrocław 2002, s. 369.

${ }^{17}$ Por. M. Klimowicz, Oświecenie, Warszawa 2006, s. 364.

${ }^{18}$ F.D. Kniaźnin, Na stoletni obchód zwycięstwa Jana III pod Wiedniem, WW, s. 94.

${ }^{19}$ F.D. Kniaźnin, Do wąsów, WW, s. 90. 
innymi Kazimierza Wielkiego, Stefana Batorego, Władysława IV Wazy, za każdym razem podkreślając ich zasługi dla narodu, nazywając ich „wzorem tronów” (w. 37) oraz „szkołą królów”20 (w. 33). Określane w dość konwencjonalny sposób postaci „wielkich dusz"21 (w. 92), jak zostają nazwane w cytowanym w tytule wystąpienia wierszu Do Ojczyzny. Vox clamantis in diserto, spotykają się z gorzką konstatacją podmiotu lirycznego:

jeśli cnót oblicze

Ze swojej ku nam obracacie chwały:

Zacni Tarnowscy, mężni Chodkiewicze!

Na cóż przykłady nam wasze zostały?

Takeśmy podli, że nas bierze trwoga

Błagać za nami zwróconego Boga. (w. 7-12)

W wielu tekstach Kniaźnin dokonuje diagnozy patriotyzmu sobie współczesnych. Niestety, nie jest ona pomyślna. Częściej niż apologia dawnych dziejów pobrzmiewa u śpiewaka Temiry patriotyczna nuta niepokoju w związku z panującą sytuacją polityczną. Wraz z nasilaniem się dramatycznej sytuacji Polski pojawiają się w jego twórczości wizje katastroficzne, opisy upadku moralności, dostrzeganie w życiu społecznym: zdrad, obojętności, uzależnienia od obcych wpływów i pieniędzy, wreszcie dochodzenia przemocą do swoich egoistycznych zachcianek. Kniaźnin traktuje Ojczyznę osobowo, w kilku lirykach pojawiają się podobnie formułowane apostrofy do Polski, określające ją „Matką” (w. 30) — jak w wierszu Do Ojczyzny. Vox clamantis in deserto i Do Ojczyzny, „Ojczyzną drogą i miłą” (w. 13) w tekście Marsz polski oraz „Ojczyzną drogą i lubą” (w. 33) w Marszu. Jest wrażliwy na to, co dzieje się w kraju. W swoich utworach odnotowuje ważniejsze wydarzenia historyczne, które rozgrywały się na jego oczach, takie jak insurekcja kościuszkowska (w tekstach: Do Tadeusza Kościuszki, Na Rewolucja 1794) czy uchwalenie Konstytucji 3 maja, szczegółowo przedstawione w Hejnale na dzień 3 Maja. Lata Sejmu Czteroletniego przynoszą nadzieję, widoczną w tekstach patriotycznych Kniaźnina, która ostatecznie zagaśnie wraz z trzecim rozbiorem Polski. Po tym wydarzeniu poeta popadnie w stan obłąkania trwający aż do końca jego dni ${ }^{22}$, co pokazuje, jak bardzo treść własnych utworów była przez niego przeżywana.

\section{Gatunki literackie charakterystyczne dla poezji patriotycznej Kniaźnina}

Teresa Skubalanka, pisząc o stylu polskiej liryki patriotyczno-obywatelskiej w epoce oświecenia, wyróżniła kilka gatunków literackich reprezentatywnych

${ }^{20}$ F.D. Kniaźnin, Do Krakowa, WW, s. 97.

${ }^{21}$ F.D. Kniaźnin, Do Ojczyzny. Vox clamantis in diserto, WW, s. 92.

22 Por. M. Klimowicz, op. cit., s. 376. 
dla tej tematyki w tym okresie ${ }^{23}$. Są wśród nich osiemnastowieczne lamenty, będące z jednej strony nawiązaniem do stylistyki barokowej, z drugiej odwołujące się do ludowej pieśni dziadowskiej, na przykład Pieśń dziada sokalskiego autorstwa Franciszka Karpińskiego. Za badaczką jako formy gatunkowe charakterystyczne dla liryki patriotycznej w XVIII wieku przyjmiemy także ody, listy poetyckie, hymny — na przykład Święta miłości kochanej ojczyzny Krasickiego. Dodać do tego należy dumy, w tym Dumy polskie Juliana Ursyna Niemcewicza, pobudki wojenne i pieśni marszowe, z Pieśnia Legionów Polskich we Włoszech na czele.

Większości tekstów patriotycznych i społecznych śpiewak Temiry nadał kształt ody ${ }^{24}$. Co oczywiste, swoją retorycznością i patetycznością oda doskonale nadawała się do prezentowania doniosłych tematów, jakimi bez wątpienia były problematyka ojczyźniana i społeczna ${ }^{25}$. Wyborem takiego gatunku wpisał się także Kniaźnin w oświeceniową tradycję Adama Naruszewicza, Jakuba Jasińskiego i innych twórców, którzy zgodnie z konwencją rozpoczynali swoje patriotyczne ody od apostrofy do konkretnych adresatów ${ }^{26}$. Tak też jest u Kniaźnina, który jednak „wyróżniając się” spośród oświeconych, często swoje teksty społeczne adresował do Boga, rozumianego starotestamentalnie jako Boga groźnego i mściwego $^{27}$, wymierzającego sprawiedliwe wyroki za nieposłuszeństwo i niewdzięczność ludzi. Niekiedy obraz ten jest przełamywany, co wyraża się wiarą w Bożą obecność oraz pokorną prośbą o miłosierdzie i pomoc, jak na przykład w liryku Do Boga [Jak samotny na ugorze...]:

Cóż mojej duszy pomoże?

Kto jej zechce stanu dociec?...

Czego szukam?... jesteś, Boże!

Ty mój przyjaciel, Ty ociec ${ }^{28}$. (w. 17-20)

To mocne powiązanie wątku patriotycznego z religijnym jest znamienną cechą dojrzałej twórczości Kniaźnina, o czym wspominają badacze zajmujący się tą tematyką. O tendencjach tych pisze Rolf Fieguth, który wskazuje, że w Lirykach szczyt rozwoju osiąga poezja religijna, ukazująca Boga, podobnie jak w mesjanizmie, jako obrońcę narodu polskiego, a jednocześnie sędziego jego licznych grze-

${ }^{23}$ Por. T. Skubalanka, Polska liryka patriotyczno-obywatelska. Studium stylu, Lublin 2012, s. $25-31$.

${ }^{24}$ Należy zaznaczyć, że niektóre liryki Kniaźnina, choć zostały nazwane odami, w rzeczywistości nie mają cech tego gatunku. Por. C. Zgorzelski, ,,W Tobie jest świattość”. Szkice o liryce religijnej oświecenia i romantyzmu, Lublin 1993, s. 19.

${ }^{25}$ Co znamienne, w twórczości patriotycznej poety z Witebska nie występują tak popularne w tym czasie elegie, częste w zbiorach Niemcewicza czy Kołłątaja.

${ }^{26}$ Por. T. Skubalanka, op. cit., s. 26.

27 Por. M. Klimowicz, op. cit., s. 365.

${ }^{28}$ F.D. Kniaźnin, Do Boga [Jak samotny na ugorze...], WW, s. 194. 
chów $^{29}$. Z kolei Bożena Mazurkowa wiąże koncentrację na tematach religijnych z poszukiwaniem przez poetę wytłumaczenia nieszczęść dotykających ojczyznę:

w parafrazach psalmów i licznych wierszach w tytule adresowanych do Boga, poszukiwał [Kniaźnin - J.Ż.] wyższego sensu dla bolesnych doświadczeń dziejowych Rzeczpospolitej, łącząc losy ojczyzny z opieką Pana ${ }^{30}$.

Czesław Zgorzelski natomiast, operując pojęciem ,patriotyczna uczuciowość", wzmiankuje, że w niektórych lirykach patriotycznych Kniaźnin zwraca się do Boga w imieniu zbiorowości, aby prosić Go o wsparcie i opiekę nad naro$\operatorname{dem}^{31}$.

Kolejnym interesującym aspektem, znamiennym dla twórczości społecznej Kniaźnina, jest rola poety, który swą „boską lutnią” ma budzić polskie sumienia oraz jak wskazywał Mieczysław Klimowicz: „przeobrażać umysły ludzkie nie zręczną argumentacją, ale wizją klęski i nieszczęścia oraz wróżbą nadziei”32. To kolejny przebłysk romantycznej lampy w twórczości poety z Witebska.

\section{Miejsce poezji patriotycznej w twórczości Kniaźnina}

Twórczość patriotyczna i społeczna Kniaźnina to dzieła poety dojrzałego. Utwory o tej tematyce zgromadził w swoich ostatnich tomach Ód, czyli liryków czterech xięgach z 1787 roku oraz w Lirykach, zbierających utwory z wcześniejszych okresów, poddane na nowo korekcie kompozycyjnej. Skupienie na tematyce obywatelskiej i patriotycznej nastąpiło u Kniaźnina od schyłku lat osiemdziesiątych XVIII wieku i było związane z burzliwymi wydarzeniami politycznymi w Rzeczypospolitej ${ }^{33}$, a także osobistymi przemianami stylu poety, który od rokokowych Erotyków i sentymentalnych Wierszy przeszedł do utrzymanych w poważnym, melancholijnym tonie Ód i Liryków, o czym pisze Rolf Fieguth w swojej najnowszej książce „, Sobie wielki”. O pięciu zbiorach lirycznych Franciszka Dionizego Kniaźnina.

Analizując teksty poety, widzimy też, jak ewoluuje nastrój odmalowywany w utworach społecznych i patriotycznych Kniaźnina — od głoszenia apoteozy wielkich przodków skontrastowanych z wadami narodowymi współczesnych pisarza, przez tony nadziei związane z takimi wydarzeniami jak uchwalenie Konstytucji 3 maja czy powstanie kościuszkowskie, po katastroficzne wizje rozbiorów aż do całkowitego złamania pióra, spowodowanego upadkiem Ojczyzny. W jego utworach odbija się wyraźnie jak w zwierciadle sytuacja polityczna kraju. Kniaź-

${ }^{29}$ Por. R. Fieguth, ,,Sobie wielki”. O pięciu zbiorach lirycznych Franciszka Dionizego Kniaźnina, Warszawa 2018, s. 253.

${ }^{30}$ B. Mazurkowa, Bóg, cnota i nadzieja w dziejowej burzy Rzeczpospolitej. „, Na Rewolucja 1794", [w:] Czytanie Kniaźnina, red. B. Mazurkowa, T. Chachulski, Warszawa 2010, s. 357.

31 Por. C. Zgorzelski, op. cit., s. 19.

32 M. Klimowicz, op. cit., s. 367.

33 Por. B. Mazurkowa, op. cit., s. 355. 
nin osobiście przeżywał to, co działo się wówczas w Polsce i dawał temu wyraz w swojej twórczości społecznej, jak też w postawie życiowej. To właśnie w jego tekstach patriotycznych błyszczy już pierwsza lampa romantyzmu, widoczna w ukazywaniu roli poety dla narodu, dyskusjach twórcy toczonych z Bogiem, pozytywnej recepcji osjanizmu oraz szczególnym posłannictwie kobiet w kształtowaniu oddanego ojczyźnie obywatela.

\section{Bibliografia}

Fieguth R., ,, Sobie wielki”. O pięciu zbiorach lirycznych Franciszka Dionizego Kniaźnina, Warszawa 2018.

Jedynak B., „Aby potomkowie byli Polakami”. Z historii refleksji nad obyczajem w oświeceniu, Lublin 2001.

Jendrysik A., Wstęp, [w:] F.D. Kniaźnin, Utwory dramatyczne. Wybór, oprac. A. Jendrysik, Warszawa 1958.

Klimowicz M., Oświecenie, Warszawa 2006.

Kniaźnin F.D., Utwory dramatyczne. Wybór, oprac. A. Jendrysik, Warszawa 1958.

Kniaźnin F.D., Wiersze wybrane, oprac. A.K. Guzek, Warszawa 1981.

Kostkiewiczowa T., Horyzonty wyobraźni. O języku poezji czasów Oświecenia, Warszawa 1984.

Kott J., Trwałe wartości literatury polskiego oświecenia, Kraków 1951.

Lenkiewiczowa J., Odbiór księżnej Izabeli Czartoryskiej przez jej współczesnych - ukazanie patriotyzmu księżnej, „Kamerton” 2006, nr 1.

Mazurkowa B., Bóg, cnota i nadzieja w dziejowej burzy Rzeczpospolitej. „Na Rewolucja 1794”, [w:] Czytanie Kniaźnina, red. B. Mazurkowa, T. Chachulski, Warszawa 2010.

Niemcewicz J.U., Do Polek, [w:] F.D. Kniaźnin, Utwory dramatyczne. Wybór, oprac. A. Jendrysik, Warszawa 1958.

Ratajczakowa D., Obrazy narodowe w dramacie i teatrze, Wrocław 1994.

Roćko A., Kontusz i frak. O symbolice stroju w XVIII-wiecznej literaturze polskiej, Warszawa 2015.

Sinko Z., Osjanizm, [w:] Stownik literatury polskiego oświecenia, red. T. Kostkiewiczowa, Wrocław 2002.

Skubalanka T., Polska liryka patriotyczno-obywatelska. Studium stylu, Lublin 2012.

Snopek J., Oświecenie. Szkic do portretu epoki, Warszawa 1999.

Stasiak A.M., Patriotyzm w myśli konfederatów barskich, Lublin 2005.

Tarnowski S., Historia literatury polskiej, t. 3, Kraków 1904.

Zgorzelski C., „W Tobie jest świattość”. Szkice o liryce religijnej oświecenia i romantyzmu, Lublin 1993.

\section{"Myż to, Polacy, owych mężów plemię..." — the place of patriotic lyrical poetry in the artistic creativity of Franciszek Dionizy Kniaźnin}

Summary

Franciszek Dionizy Kniaźnin, although known primarily as the author of love and religious poetry, devoted many of his texts to patriotism. His view on the issues of the fatherland evolved - 
from works which praised great ancestors and stigmatized national flaws, through lyric poems filled with hope inspired by the events of 1791-1794, through catastrophic visions related to the partitions of Poland, to the complete cessation of poetic activity after the fall of his homeland. Kniaźnin's patriotic work also clearly announces the advent of Romanticism, evident in its presentation of the key role that poets should play in the nation, the artist's discussions with God, the positive reception of Ossianism and the special mission that women have of shaping bringing up citizens devoted to their homeland.

Keywords: Franciszek Dionizy Kniaźnin, patriotic lyric poetry, evolvement of literary work, partitions of Poland, Romantic themes 